\title{
Ion transporters in the root nodule of Medicago truncatula: potassium transporters
}

Fedorova E.E., Trifonova N.A.

K.A. Timiryazev Institute of Plant Physiology RAS, Moscow, Russia

E-mail elenafedorova06@mail.ru

Key message. The transporter proteins were mistargeted and partly depleted from plasma membrane of mature infected cells, this phenomenon may contribute to the potassium loss by symbiosomes during their development and senescence.

Keywords: root nodule, legume/Rhizobium symbiosis, membrane potassium transporters.

The root nodule is a temporary short-lived organ, an ecological niche in the plant tissue for nitrogen-fixing bacteria of the rhizobium genus. Based on the data on high sensitivity of root nodules to ionic stresses (Coba de la Peña et al., 2010, Noori et al., 2016) we hypothesized that infected nodule cells may have physiological defects in maintaining ion balance. Ionic status, in turn, depends on the expression and localization of membrane ion transporters. A preliminary analysis of ion's distribution in the symbiosomes and vacuoles of infected cells, performed by energy dispersive spectrometry with X-ray microanalysis and scanning microscopy, showed that infected cells lose potassium during ontogenesis. In order to identify the causes of this phenomenon, a study was conducted of two key plant-based potassium carriers with opposite potassium transfer vectors: inwardly rectifying potassium transporter MtAKT1 and Outward Rectifier potassium channel MtSKOR.

Both transporters were expressed in the meristem, zone of active nitrogen fixation, and in senescence zone. In uninfected cells, MtAKT and MtSKOR were localized on the cytoplasmic membrane. In mature infected cells, the localization of proteins was impaired. We observed a partial loss of transporters from cytoplasmic membrane. The MtSKOR protein was redirected to the symbiosome membrane. The relocation of this transporter while maintaining the transport vector, can contribute to the potassium loss from symbiosomes. The flaws of the localization of membrane transporters may be one of the reasons for the decrease in the potassium availability for the symbiosomes and vacuoles of infected cells during their ontogenesis.

The work is supported by the Russian Science Foundation (project №19-04-00570A).

\section{Ионные транспортеры в корневом клубеньке Medicago truncatula: переносчики калия.} Федорова Е.Э., Трифонова Н.А.

Федеральное государственное бюджетное учреждение науки Институт физиологии растений им. К.А. Тимирязева РАН, Москва, Россия

Аннотация. Нарушение локализации белков ионных транспортеров в инфищированных клетках клубенька может приводить к уменьшению доступности калия для симбиосом.

Ключевые слова: корневой клубенек, бобово-ризобиальный симбиоз, мембранные транспортеры калия.

Корневой клубенек является временным короткоживущим органом, экологической нишей в растительной ткани для азотфиксирующих бактерий рода ризобиум. Основываясь на данных о высокой чувствительности корневого клубенька к ионным стрессам (Coba de la Peña et al., 2010, Noori et al., 2016) мы предположили, что инфицированные клетки клубенька могут иметь физиологические дефекты в поддержании ионного баланса. Ионный статус, в свою очередь, зависит от экспрессии и локализации мембранных переносчиков ионов. Предварительный анализ содержания ионов в симбиосомах и вакуолях инфицированных клеток, выполненный с использованием энергодисперсионной спектрометрии с рентгеновским микроанализом и сканирующей микроскопии показал, что инфицированные клетки в процессе онтогенеза теряют калий (Fedorova et al., 2020 (in press). С целью выявления причин этого явления было проведено исследование двух ключевых растительных переносчика калия с противоположными векторами переноса калия: канал входящего направления МtАКТ и канал выходящего направления MtSKOR.

Экспрессия переносчиков в клубеньке отмечена в зоне меристемы, зоне активной азотфиксации и в зоне старения. В неинфицированных клетках MtAKT и MtSKOR были локализованы на цитоплазматической мембране. В зрелых инфицированных клетках локализация белков была нарушена, была отмечена частичная потеря переносчиков цитоплазматической мембраной. Происходило перенаправление белка MtSKOR к симбиосомной мембране, что, при сохранении вектора транспорта, может способствовать выносу калия из симбиосом. Нарушение локализации мембранных переносчиков может быть одной из причин уменьшения содержания калия в симбиосомах и вакуолях инфицированных клеток.

Работа поддержана Российским научным фондом (проект № 19-04-00570А).

Coba de la Peña T, Redondo FJ, Manrique E, Lucas MM, Pueyo JJ. 2010. Nitrogen fixation persists under conditions of salt stress in transgenic Medicago truncatula plants expressing a cyanobacterial flavodoxin. Plant Biotechnol. J. 8, 954-965.

Noori F, Etesami H, Zarini HN, Khoshkholgh-Sima NA, Salekdeh GH, Alishahi F. 2018. Mining alfalfa (Medicago sativa L.) nodules for salinity tolerant non-rhizobial bacteria to improve growth of alfalfa under salinity stress. Ecotoxicology and Environmental Safety 162, 129-138. 